\title{
Commentary Article History Behind the Closed Sardine Fishing in the Zamboanga Peninsula
}

\author{
Roberto A. Baylosis ${ }^{1}$ \\ ${ }^{1}$ Executive Vice-President, SOPHIL Fishing Association, Inc., \\ Torre de la Buenavista, Buenavista Street, Zamboanga City \\ Communicated by Ephrime B. Metillo*, \\ Editorial Board Member, The Philippine Journal of Fisheries \\ E-mail address: ephrime.metillo@g.msuiit.edu.ph*
}

$\mathbf{F}$ irst of all, I would like to share some personal background of my involvement with this noble advocacy of sardine fishery conservation in the Zamboanga Peninsula. I have been with the commercial fishery sector for about 46 years to date, spent 28 years in the tuna fishing sector, started as a fisherman onboard, rose from the ranks, and was eventually assigned in land-based functions. Presently, I am connected with the SOPHIL Fishing Association, Inc. in Zamboanga City, for about 18 years already.

The author became a fisherman because while on a summer vacation as a working college student then, an opportunity for a summer job in 1972 for students on vacation was made available on board a medium class fishing boat from a Manila-based tuna fishing outfit, EPHIROL Fishing Enterprises, Inc. (EFEI) with office at Intramuros, Manila. EFEI has just opened and recruited fishermen in Sarangani Province through a business branch outfit unit. Perhaps the management was satisfied with my performance as I received a series of rank promotions and eventually was transferred to handle land-based functions. The undersigned have served the Tuna Fishing Sector for about 28 years, on board along with Japanese master fishermen, Yoshibumi Kihara and Osamu Taniguchi for squid fishing, tuna long line, shrimps trawl, tuna purse, dog sharks fishing, and skipjack tuna of the Katsubushi Processing Plant, a branch processing plant of EFEI.

The sardine closed fishing advocacy started around 2002-2003, while I was connected with a sardine fishing company engaged in sardine canning and purse seine fishing for sardines based in Zamboanga City. Engr. Rogelio De Sosa, a co-employee, discussed what he viewed on television regarding the sardine collapse in California. Aware of the collapse of other sardines fishery stocks of other countries several years back, the undersigned felt alarmed that the collapse of the California sardines could happen in Zamboanga. Together with a co-employee, we approached our employer, which eventually led to a meeting with Mr. Francisco Cadiz Jr. and the late Mr. Abdul Gapor Abdua, Director of the Bureau of Fisheries and Aquatic Resources (BFAR) Region IX that time, and discussed how to possibly prevent the collapse of the sardine fishery stock in Eastern Sulu Sea. Mr. Abdua assigned two enumerators in the fish port/landing that caters for the fishing boats, a facility that is also owned and operated by the company, which is supervised by our employer. However, the budget for the said sardine catch monitoring task was not sustained for long.

My advocacy to protect the sardine stock was heard by the Zamboanga City Council which promulgated City Resolution no. 1199. I have consulted the matter with former BFAR Director and DA Undersecretary Asis Perez and he named me as a prime mover during a lunch break in a gathering last August 17, 2017, as per letter attached addressed to the two city councilors, Hon. Kim Elago and Hon. Asbi Edding.

As a backgrounder, the sardine fishing companies based in Zamboanga City are mostly members of an association named the Southern Philippines Deep Sea Fishing Association, Inc., presently renamed as, per corrected SEC Registration, as SOPHIL Fishing Association, Inc. There were 16 member fishing companies at the start which increased to 20. The president then was my employer, and it was a big opportunity to be able to relay and convince the members during association meetings for a closed fishing season for proper management and sustainability of the resources referring to Section 9 of the RA 8550. This is to prevent a similar occurrence with the collapse of the California sardines. In 2005 with handful members who consented to the advocacy, I took the initiative to inquire former coemployee Mr. Samuel Resma, who was in constant contact with me and was then in the United States on a Fulbright scholarship study on fishery stock assessment. Taking the advice of Samuel, I was able 
to meet a certain Dr. Stanley Swerdloff, the fishery adviser of the Growth Equity in Mindanao (GEM) based in Davao City. Several meetings happened with Dr. Swerdloff especially during his trips to Tawi Tawi passing by Zamboanga to inspect and supervise a GEM-sponsored project in Bongao. Dr. Stanley Swerdloff was very helpful in suggesting how to possibly adopt the conservation measure that I advocated. The concepts of upwelling and plankton were shared by Dr. Swerdloff. Meetings were carried out to discuss submission of fishing activity and harvest records which was attended by fishing company representatives, Dr. Swerdloff, myself, and Mr. Samuel Resma, who has already returned in the country after the two-year study in the United States and became connected with Mindanao Development Authority (MinDA) formerly Mindanao Economic Development Council (MEDCo). Several meetings lead to the crafting of the sardine management plan by Dr. Stanley Swerdloff that he himself submitted the draft to the BFAR Central Office. While in the process of gathering data for the sardine management plan, Mr. Edgar Lim, who has been with the processing sector since 1985, also initiated actions to convince the fishing operators supplying their raw materials and some cannery operators/managers for the observation and practice of the sardine closed fishing.

Realizing the urgency of the matter, we did not wait for the response from the BFAR Central Office. We raised the sardine stock concern at the National Fishery and Aquatic Resource Management Council (NFARMC). The opportunity came when I was invited as an observer in one of the NFARMC meetings sometime in 2009. I then raised the advocacy and provided the NFARMC a copy of the draft management plan crafted by Dr. Swerdloff. The reaction of the vice chairperson then was not favorable for the closed fishing period proposed, mentioning that the proposed period was self-serving and lacking science-based research and studies. In that meeting, the former BFAR IX Regional Director, who was also the head of Region IX National Stock Assessment Program, was also present. There were no reactions from both former Undersecretary Perez and the BFAR IX NSAP head and Regional Director Ahadulla Sajili. The proposed closed fishing period was based on our collaboration with the receiver processors of sardine raw materials and believed that the period proposed was appropriate based on the observation of the presence of gonads in the sardines supplied to the canneries during the said period. The most significant of which was the scientific input from the National Fisheries Research \& Development Institute (NFRDI) through scientists Mr. Noel Barut and Dr.
Mudjekeewis D. Santos who were our partners in the Sulu-Sulawesi Large Marine Ecosystem project. Mr. Barut and Dr. Santos were our resource persons on the reproductive biology of sardines. This closed fishing advocacy was also raised and discussed in the Region IX Regional Development Council and MEDCo, presently MinDA; the latter supported for the implementation of the proposal.

With my personal pleading during fisheryrelated gatherings and the involvement of various government concerned agencies, the Department of Agriculture-Department of Interior and Local Government Joint Administrative Order No. 1 (DA/ DILG JAO No. 1) was passed to implement the sardine closed fishing for three months starting Nov 15, 2011. The SOPHIL Fishing operators implemented DA/DILG JAO No. 1 following the period that was originally proposed that isww December 1 to March 1 the following year. The implementation was carried out with the intervention support of the Industrial Group of Zamboanga (IGZI) President Engr. George Ledesma. IGZI is an organization of allied industries with some sardine canning factory members.

After three years of practice per DA/DILG JAO No. 1, Mr. Edgar Lim and I became members of the NFARMC, and the opportunity was our very chance to propose for the continued closed fishing. During the NFARMC regular meeting on September 2014, the NFARMC recommended for the passage of the Bureau Administrative Circular No. 255 (BAC 255) thereafter establishing the seasonal fishing closure for sardine conservation. Around this time more scientific studies funded by the Department of Science and Technology (DOST) have been conducted by Philippine academic institutions: University of the Philippines (UP) Marine Science Institute, UP Visayas, UP Los Baños, Mindanao State University (MSU) Iligan Institute of Technology, MSU Naawan, and Jose Rizal Memorial State University. BFAR also initiated oceanographic validation surveys on sardine larvae distribution and abundance in the Sulu Archipelago and the Zamboanga Peninsula sectors of Sulu Sea. Studies carried out in Zamboanga Peninsula waters were on physical oceanography of the coastal upwelling, plankton, sardine biology, and socioeconomic aspects. Meanwhile, continued research on the reproductive biology as part of stock assessment is implemented by NFRDI. The National Sardine Management Plan has also been initiated by BFAR as of the writing of this article.

The closed fishing practice is now on its 7th year starting with the passage of the DA/DILG JAO No. 1 and the BAC 255. 